\title{
Could the umbel order selection and GA3 treatment improve seed germination in Amazon chicory species?
}

\author{
Larissa da Fonseca Moraes ${ }^{1}$ (D), Francisco Laurimar do Nascimento Andrade ${ }^{1, \star}$ (iD), Rafaelle Fazzi \\ Gomes $^{1}$ (D), Lucas da Silva Santos² ${ }^{2}$ D \\ 1. Universidade Federal Rural da Amazônia - Capanema (PA), Brazil. \\ 2. Fundação Universidade Federal de Rondônia, Departamento de Agronomia - Rolim de Moura (RO), Brazil. \\ Received:Sep. 13, 2020 | Accepted: Mar. 10, 2021 \\ Section Editor: Hector Valenzuela \\ *Corresponding author: franlaurimar@gmail.com \\ How to cite: Moraes, L. F., Andrade, F. L. N., Gomes, R. F., Santos, L. S. (2021). Could the umbel order selection and GA3 treatment improve \\ seed germination in Amazon chicory species? Bragantia, 80, e3021. https://doi.org/10.1590/1678-4499.20200404
}

\begin{abstract}
This study aimed to estimate the production of seeds per umbel and to assess both the effect of gibberellic acid (GA3) and umbel order on seed germination in Amazon chicory species. The experiment was conducted in two steps. Firstly, traits related to seed production were evaluated. Afterward, a germination test was carried out, and the following parameters were assessed: germination speed index (GSI), average germination time (AGT), germination percentage (\%G), percentage of abnormal seedlings (\%AS), and percentage of non-germinated seeds (\%NGS). Remarkably, there was strong interaction between the analysed factors. The highest production of seeds per plant was observed in the treatment containing the blend of seeds from different umbels $\left(1.41 \mathrm{~g} \cdot\right.$ plant $\left.^{-1}\right)$, in which the number of umbels by order and the total number of seeds per plant were the major traits related to the improved yield. The application of GA ${ }_{3}$ at $200 \mathrm{mg} \cdot \mathrm{dm}^{-3}$ increased \%G in second-order seeds. Regardless of $\mathrm{GA}_{3}$ application, seeds from secondary umbels showed shorter AGT by up to two days, while no difference in GSI was observed. Collectively, these results offer novel and timely information on the seed germination behavior in Amazon chicory, revealing practical advice of utmost importance for local producers.
\end{abstract}

Key words: Eryngium foetidum, gibberellin, growth regulators, seed production.

\section{INTRODUCTION}

Seed dormancy has an ecological function in several plant species and it is one of the main means of survival and preservation in adverse ecosystems. However, it may also affect seed germination itself, impairing a proper plant stand in the field (Prudente and Paiva 2018). The dormancy mechanism is classified as endogenous when the factors are linked to the embryo growth restriction, or exogenous-when it involves the integument, pericarp or epicarp, or both, by presenting physical, mechanical, or chemical barriers (Lopes and Nascimento 2012).

The Amazon chicory (Eryngium foetidum L.) is a vegetable from the Apiaceae family, native to Central and Latin America, and belongs to the group of non-conventional vegetables (Gomes et al. 2013). This species has significant importance for food security, cultural value, and job availability in tropical regions (Paul et al. 2011).

As an umbelliferous species, it presents an indeterminate flowering pattern consisting of different inflorescence orders called umbels (Singh et al. 2014). In these plants, the presence of seeds at distinct stages is quite common, a feature that makes it difficult to obtain satisfactory germination percentages (Ekpong and Sukprakarn 2006).

Due to the non-synchronized ripening and reduced size of the seeds, producers of chicory combine the seeds from all inflorescence orders to reach a satisfactory number of seeds for sowing. This is a usual method performed by producers from North Brazil. However, according to Ekpong and Sukprakarn (2006), the lack of uniformity in seed growth, the filling, and the maturation throughout the umbel orders are the main causes of impairment in the overall quality of plant stands. 
In addition, Mozumder and Hossain (2013) and Mozumder et al. (2017) have demonstrated that chicory seeds likely present some degree of dormancy, which hinders germination ability even when it is viable. According to these authors, the potential cause of the low germination rates in such species may be a consequence of a chemical dormancy imposed by coumarin, but this is not considered by Baskin and Baskin (2004), which do not take into account the chemical dormancy classification. Thus, precise results on the isolated effects of coumarin on germination have not been yet demonstrated.

Coumarin is a secondary metabolite synthesized in leaves, and it is also found at higher levels in fruits, roots, and stems. Moreover, environmental conditions and seasonal changes can influence coumarin production in different organs of the plant (Asif 2015). This metabolite holds the potential to inhibit seed germination, root growth, water absorption, photosynthesis, among many other processes in the plant (Hussain et al. 2018). The presence of coumarin in the Amazon chicory species is associated with the fact that the Apiaceae is one of the principal families to produce this compound, presenting almost all known types of coumarins (Ribeiro and Kaplan 2002; Razavi 2011).

Chen et al. (2019), studying the effects of coumarin on rice seed germination, observed that radicle emergence was delayed by coumarin via impairment of both abscisic acid catabolism and production of reactive oxygen species $\left(\mathrm{O}_{2}\right.$ and $\left.\mathrm{H}_{2} \mathrm{O}_{2}\right)$ in the embryo in a dose-dependent manner. These responses were then associated with rice seed germination inhibition.

To overcome the barriers imposed by seed dormancy, among other resistances, it is recommended the use of growth regulators. In this vein, gibberellins are the principal substances involved in critical germination events (Debeaujon and Koornneef 2000). Gibberellic acid $\left(\mathrm{GA}_{3}\right)$ is one of the most frequent gibberellin derivatives used for seed germination and seedlings establishment, due to its ability to promote cell elongation, embryo growth, and seedling emergence, contributing to uniform plant stands (Lavagnini et al. 2014). However, suitable environmental conditions, as well as elicitor compounds, that provide higher seed germination rates in Amazon chicory species, are critically unknown.

In this context, it seems fundamental to study about the ideal conditions to guarantee high seed germination rates in Amazon chicory, mainly by considering the influence of umbel orders on the seed germination behavior. Therefore, this study aimed to estimate the production of seeds by umbels and to assess the effect of umbel order and GA3 on seed germination in Amazon chicory species.

\section{MATERIAL AND METHODS}

The assay was conducted at the Laboratory of Biodiversity of the Universidade Federal Rural da Amazônia (UFRA),

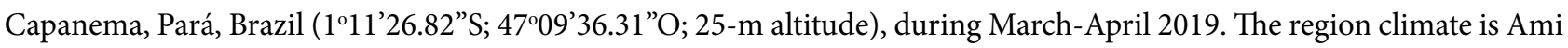
type, according to Köppen-Geiger's classification system, characterized as humid mega-thermal, with annual temperature, relative humidity, and precipitation corresponding to $26^{\circ} \mathrm{C}, 85 \%$, and $2,500 \mathrm{~mm}$ on average, respectively (Alvares et al. 2013).

The Amazon chicory seeds were produced at the experimental farm in Igarapé-Açu, Pará, Brazil ( $1^{\circ} 07^{\prime} 48.47^{\prime \prime} S$; 47036 $45.31^{\prime \prime} \mathrm{W}$; 54-m altitude), in an arch-type greenhouse, 51-m long, $14-\mathrm{m}$ wide, 3.5-m high, covered with a 150- $\mu \mathrm{m}$-thick translucent polyethylene plastic film.

The experimental design was in randomized blocks, with four treatments and six replications regarding seed production assessment. The treatments consisted of seeds collected from several inflorescence orders (Fig. 1): first order, second order, third order, and a blend of seeds from the orders of inflorescence (a widely used practice followed by chicory seed producers). Each plot consisted of 20 plants, with 10 plants within the plot used for evaluations.

To produce chicory seedlings, five seeds per cell were sown in a polystyrene tray with 200 cells, filled with commercial substrate Tropstrato ${ }^{\circledast}$. After sowing, the trays were placed on a bench under a covered environment with a $50 \%$-shading screen, in which they were irrigated manually twice a day-in the morning and in the afternoon ( 7 a.m. and 5 p.m.). At 20 days after sowing (DAS), thinning was performed, to one seedling per cell.

Seedlings with four well-developed permanent leaves (95 DAS) were transplanted and set out in a spacing of 0.20 (between rows) $\times 0.20 \mathrm{~m}$ (between plants). The plants were grown into dystrophic Yellow Argisol, with sandy texture. The soil analysis was accomplished in the arable layer depth $(0-20 \mathrm{~cm})$, which presented the following physicochemical characteristics: $\mathrm{pH}_{\mathrm{H} 2 \mathrm{O}}=3.95 ; \mathrm{P}=4 \mathrm{mg} \cdot \mathrm{dm}^{-3} ; \mathrm{K}+=0.55 \mathrm{mmol} \cdot \mathrm{dm}^{-3} ; \mathrm{Ca}^{+2}=5.8 \mathrm{mmol} \cdot \mathrm{dm}^{-3} ; \mathrm{Mg}^{+2}=3 \mathrm{mmol} \cdot \mathrm{dm}^{-3}$; $\mathrm{Al}+=5.4 \mathrm{mmol}_{c} \cdot \mathrm{dm}^{-3} ; \mathrm{H}+\mathrm{Al}=46.5 \mathrm{mmol}_{c} \cdot \mathrm{dm}^{-3} ; \mathrm{SB}=9.35 \mathrm{mmol}_{c} \cdot \mathrm{dm}^{-3} ; \mathrm{CTC}=56.3 \mathrm{mmol}_{c} \cdot \mathrm{dm}^{-3} ;$ and $\mathrm{V}=17.31 \%$. 


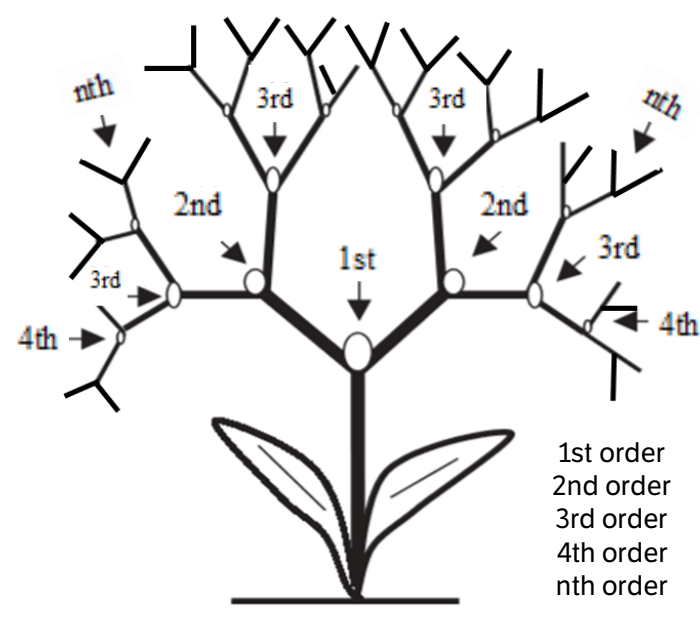

Figure 1. Floral stem pattern of inflorescence orders in Eryngium foetidum L.

Source: Adapted from Ekpong and Sukprakarn (2006)

Fertilization was carried out based on soil chemical analysis, as recommended for leafy vegetables in Pará state (Cravo et al. 2007). Watering was performed by a drip watering system, with self-compensating pipes equipped with sprinklers spaced every $15 \mathrm{~cm}$, in a flow of $2 \mathrm{~L} \cdot \mathrm{h}^{-1}$. The irrigation system was activated once a day until reaching field capacity.

Pruning was performed once a week after flower bud initiation to differentiate umbel orders and to make it easier for seed harvesting, and it was implemented only for first, second, and third orders treatments. Thus, no pruning was carried out for the blend of seeds treatment.

The inflorescence harvesting started on the $84^{\text {th }}$ day after transplanting (DAT), when it changed color from green to brown. The inflorescences were harvested following their respective order, packed in paper bags, and dried at room temperature for five days. Subsequently, the seeds were removed from the inflorescences and stored in a refrigerator.

After seed processing, the following characteristics were then evaluated:

- Number of umbels per order (NUO);

- Number of seeds per umbel (NSU);

- Mass of 100 seeds (M100) (g), based on the sample weight of 100 seeds;

- Total number of seeds per plant (TNSP), obtained by summing the NSU order;

- Seed production per plant (SPP) $\left(\mathrm{g} \cdot \mathrm{plant}^{-1}\right)$, calculated based on the total mass of seeds per plant (Ekpong and Sukprakarn 2006).

The moisture content was evaluated in pre- and post-storage conditions when the seeds were stored in a refrigerator at $\pm 10^{\circ} \mathrm{C}$. The moisture percentage was calculated based on the wet weight, as recommended by Brasil (2009).

The germination tests in $\mathrm{GA}_{3}$-treated seeds were arranged in a completely randomized design with a $4 \times 5$ factorial scheme. The first factor consisted of the seeds obtained according to their respective umbel order (first, second, third, and a mixture of the orders), and the second factor constituted five doses of gibberellic acid (0, 50, 100, 150, and $\left.200 \mathrm{mg} \cdot \mathrm{dm}^{-3}\right)$, totalling 20 treatments, with three replicates of 50 seeds each.

$\mathrm{GA}_{3}$ solutions were prepared from an initial stock solution, concentrated in $500 \mathrm{mg} \cdot \mathrm{dm}^{-3}$, which was subsequently diluted to meet desired concentrations, as described by Quisen and Angelo (2008).

The seeds were then placed in a Gerbox, protected by aluminium foil, containing three sheets of germitest paper saturated with $\mathrm{GA}_{3}$ solution, under concentrations of $0,50,100,150$ and $200 \mathrm{mg} \cdot \mathrm{dm}^{-3}$, using a fraction of 2.5 times the weight of the dried paper mass, as the moistened paper. Then, the seeds were placed in a biochemical oxygen demand (BOD) growth chamber, model SL-200, brand SOLAB ${ }^{\odot}$, at the constant temperature of $25^{\circ} \mathrm{C}$ and $80 \%$ relative humidity, during 48 hours in the dark, to avoid molecule degradation. 
After $48 \mathrm{~h}$, the aluminium foil was removed, and temperature and relative humidity were set up to $26^{\circ} \mathrm{C}$ and $60 \%$, respectively, under 12 hours of light.

Germinated seeds were counted 30 days after experiment initiation. Germinated seeds presenting primary root protrusion were selected for assessment of the germination speed index (GSI) and average germination time (AGT).

At the end of the experiment, non-germinated seeds (dormant or dead) and abnormal seedlings (AS) were sorted. According to the Rules for Seed Analysis (RAS), these seedlings can be classified as damaged, deformed, deteriorated, and with small defects (Brasil 2009). For both analyses, a stereoscope, model OPZTS Standard ${ }^{\circledR}$, was used.

The following characteristics were also evaluated:

- GSI, calculated according to Maguire (1962);

- AGT, obtained by counting the germinated seeds every two days until the $20^{\text {th }}$ DAS, as described by Labouriau (1983);

- Germination percentage $(\% \mathrm{G})$, calculated through the Equation 1:

$$
\mathrm{G}=[(\mathrm{N} / 50) \times 100]
$$

in which: $\mathrm{N}=$ number of germinated seeds at the end of the test.

The results were expressed as an average of percentage, based on the number of normal seedlings (Brasil 2009);

- Percentage of AS (\%AS), obtained by the Equation 2:

$$
\mathrm{PA}=[(\mathrm{NPA} / 50) \times 100]
$$

in which: NPA = number of abnormal seedlings at the end of the test (Brasil 2009);

- Percentage of non-germinated seeds (\%NGS), obtained by the Equation 3:

$$
\mathrm{NGS}=[(\mathrm{TNGS} / 50) \times 100]
$$

in which: \%NGS = total of non-germinated seeds.

Data from seed production were previously evaluated to the assumptions of analysis of variance (ANOVA)-normality and homoscedasticity-, by the Lilliefors and Levene's tests. Then, these data were submitted to ANOVA, with the means compared by the Tukey test at $5 \%$ probability. In addition, a simple correlation analysis was performed. These analyses were conducted via AgroEstat software (Barbosa and Maldonado Júnior 2015). For germination data as a function of GA3 doses and umbels order, a polynomial regression analysis was carried out. The analyses were also performed by AgroEstat (Barbosa and Maldonado Júnior 2015).

\section{RESULTS AND DISCUSSION}

By evaluating seed production in Amazon chicory under a protected environment, differences were observed in the NUO, M100, TNSP and SPP (Table 1).

For NUO, the blend of seeds treatment (current method used by local producers) differed significantly from its counterparts (Table 1). This behavior was expected, since the number of inflorescences (umbel type) increases with the number of orders or branches by the stem, which leads to a higher number of seeds. Thus, given that, there is no commercial seed production for this species; producers save part of this production for seed collection.

Regarding the NSU, no significant difference was observed (Table 1). However, an overall average of 76 seeds per umbel was verified. This outcome is relevant due to the lack of reports on this vegetable species in the current literature. Hence, 
this information may be used for further estimates of seed production in Amazon chicory species. For the M100, the blend of seeds treatment showed statistical differences (Table 1).

Table 1. Number of umbels per order (NUO), number of seeds per umbel (NSU), mass of 100 seeds (M100), total number of seeds per plant (TNSP), and seed production per plant (SPP) in Amazon chicory, according to the orders of umbels.

\begin{tabular}{|c|c|c|c|c|c|}
\hline Umbels orders & NUO & NSU & M100 & TNSP & SPP $\left(g \cdot\right.$ plant $\left.^{-1}\right)$ \\
\hline $1^{\text {st }}$ order & $1 \mathrm{~d}$ & $76 a$ & $0.005 \mathrm{~b}$ & $307.0 \mathrm{c}$ & $0.097 c$ \\
\hline $2^{\text {nd }}$ order & $2 c$ & $73 a$ & $0.007 a b$ & $485.0 \mathrm{c}$ & $0.205 c$ \\
\hline $3^{\text {rd }}$ order & $4 \mathrm{~b}$ & $78 a$ & $0.004 b$ & $1,076.0 \mathrm{~b}$ & $0.510 \mathrm{~b}$ \\
\hline Blend & $21 a$ & - & $0.011 \mathrm{a}$ & $8,538.0 \mathrm{a}$ & $1.411 \mathrm{a}$ \\
\hline F test & $67.65^{*}$ & $1.18^{\mathrm{ns}}$ & $7.62^{*}$ & $150.21^{*}$ & $59.57^{\star}$ \\
\hline CV (\%) & 28.23 & 8.33 & 1.47 & 4.08 & 18.25 \\
\hline
\end{tabular}

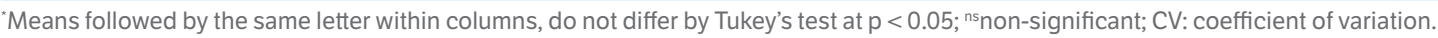

According to Ekpong and Sukprakarn (2006), the prevalence of heavy seeds in chicory may reflect a physiological quality, since it suggests a higher quantity of reserve compounds in the embryo, which is more evident in the first order due to the longer time for seed filling. However, in this study, such behavior was not observed, since the blend of seeds from different orders presents distinctions in seed physiological maturity, size, and water content (Marcos Filho 2015), making it difficult to obtain seed of uniform size and maturity from the seed blends. Thus, further studies on the seed biomass of Amazon chicory species are still required.

For TNSP, the blend of seeds differed significantly from the other treatments (Table 1). The highest obtained values are related to the higher number of umbels observed in each order, as the seed blend encompasses only the first ten orders. The response verified in TNSP appears to be associated with the total number of umbels in each order, given that the higher the order the higher the number of umbels, which reflects in the significant number of seeds observed in this treatment (Ekpong and Sukprakarn 2006). It is worth mentioning that local Amazon chicory producers use such practice to obtain their seeds.

For SPP, the blend of seeds showed significant difference and, therefore, better performance (Table 1). These results are closely related to those found for the TNSP. Ekpong and Sukprakarn (2006) reported that the seventh and eighth inflorescence orders contribute markedly to the total seed yield in E. foetidum in Thailand, while the seeds from the first order presented little influence on the production. According to the same authors, these responses are expected in studies concerning umbelliferous plants because, in addition to the number of umbels varying within the orders, they present an undetermined flowering pattern with continuous production of inflorescences.

By analysing the correlation indexes between the characteristics of production in Amazon chicory seeds, a strong consonance is observed with the results previously presented, in a manner that NUO and TNSP showed high correlation for the production of SPP, which demonstrates a direct benefit to higher seed productivity (Table 2).

Table 2. Simple linear correlation matrix between production characteristics in Amazon chicory seeds according to the umbel orders.

\begin{tabular}{cccc}
\hline \multirow{2}{*}{ Parameters } & \multicolumn{3}{c}{ Coefficient of correlation } \\
\cline { 2 - 4 } & NUO & TNSP & PROD \\
\hline TNSP & $0.99^{\star *}$ & - & - \\
\hline PROD & $0.98^{*}$ & $0.98^{*}$ & - \\
\hline M100 & $0.86^{\text {ns }}$ & $0.89^{\text {ns }}$ & $0.83^{\text {ns }}$ \\
\hline
\end{tabular}

TNSP: total number of seeds per plant; PROD: seed production per plant; M100: mass of 100 seeds; NUO: number of umbels per order; "significance 5\%; "significance 1\%; "

According to Nakagawa (2014), it is important to exploit components of seed yield and their interrelationships. In this context, the number of inflorescences, number of plants per unit area, number of inflorescence seeds, and 
seed mass are the key yield-related variables. The present study indicate that the NUO and the TNSP are the most important variables to evaluate seed productivity in E. foetidum. Finally, there was no significant correlation between the M100 and other characteristics.

Regarding the germination tests as a function of GA3 doses, an interaction was observed between factors of umbel orders and $\mathrm{GA}_{3}$ doses with respect to GSI, \%G, \%AS and \%NGS (Table 3). In contrast, the AGT showed significant difference when inflorescence order was considered as a factor. The seeds used in this stage showed the average of $6 \%$ moisture content, a value commonly observed in seeds of several vegetables in which it ranges from 5 to $7 \%$ (Costa 2012).

Table 3. Summary of the analysis of variance for germination speed index (GSI), average germination time (AGT), germination percentage $(\% G)$, percentage of abnormal seedlings (\%AS) and percentage of non-germinated seeds (\%NGS), as a function of inflorescence orders and $\mathrm{GA}_{3}$ doses in Amazon chicory.

\begin{tabular}{|c|c|c|c|c|c|}
\hline \multirow{2}{*}{ Variable source } & \multicolumn{5}{|c|}{ F values } \\
\hline & GSI & AGT & $\% G$ & $\%$ AS & $\%$ NGS \\
\hline Inflorescence order (O) & $11.77^{\star}$ & $4.92^{*}$ & $5.48^{*}$ & $11.45^{\star}$ & $12.89^{*}$ \\
\hline $\mathrm{GA}_{3}$ doses $(\mathrm{D})$ & $15.53^{*}$ & $1.16^{\mathrm{ns}}$ & $11.23^{*}$ & $8.89^{*}$ & $15.94^{*}$ \\
\hline Interaction $\mathrm{O} \times \mathrm{D}$ & $6.17^{*}$ & $1.18^{\text {ns }}$ & $8.14^{*}$ & $5.38^{*}$ & $6.78^{*}$ \\
\hline CV (\%) & 11.99 & 18.24 & 34.64 & 18.15 & 18.65 \\
\hline Inflorescence order & & AGT & & & \\
\hline $1^{\text {st }}$ order & & $9.82 a b$ & & & \\
\hline $2^{\text {nd }}$ order & & $8.98 b$ & & & \\
\hline $3^{\text {rd }}$ order & & $10.14 a b$ & & & \\
\hline Blend & & $11.52 \mathrm{a}$ & & & \\
\hline DMS & & 1.80 & & & \\
\hline
\end{tabular}

Means followed by the same letter do not differ by Tukey's test at $\mathrm{p}<0.05$; CV: coefficient of variation; DMS: difference minimum significant; n'non-significant.

Figure 2 shows that the different doses of $\mathrm{GA}_{3}$ associated with the umbels blend provided an increased GSI as a function of the dose of $\mathrm{GA}_{3}$, with a maximum value of 2.42 . Thus, the optimal dose estimated by the adjustment equation $(\mathrm{R} 2=0.90)$ was $195 \mathrm{mg} \cdot \mathrm{dm}^{-3}$ for a GSI of 2.34 . It should be noted that the first-order treatment obtained a better adjustment to the model ( $\mathrm{R} 2=0.95)$. However, it was neglected by presenting lower values of GSI and low SPP, which restrict its recommendation.

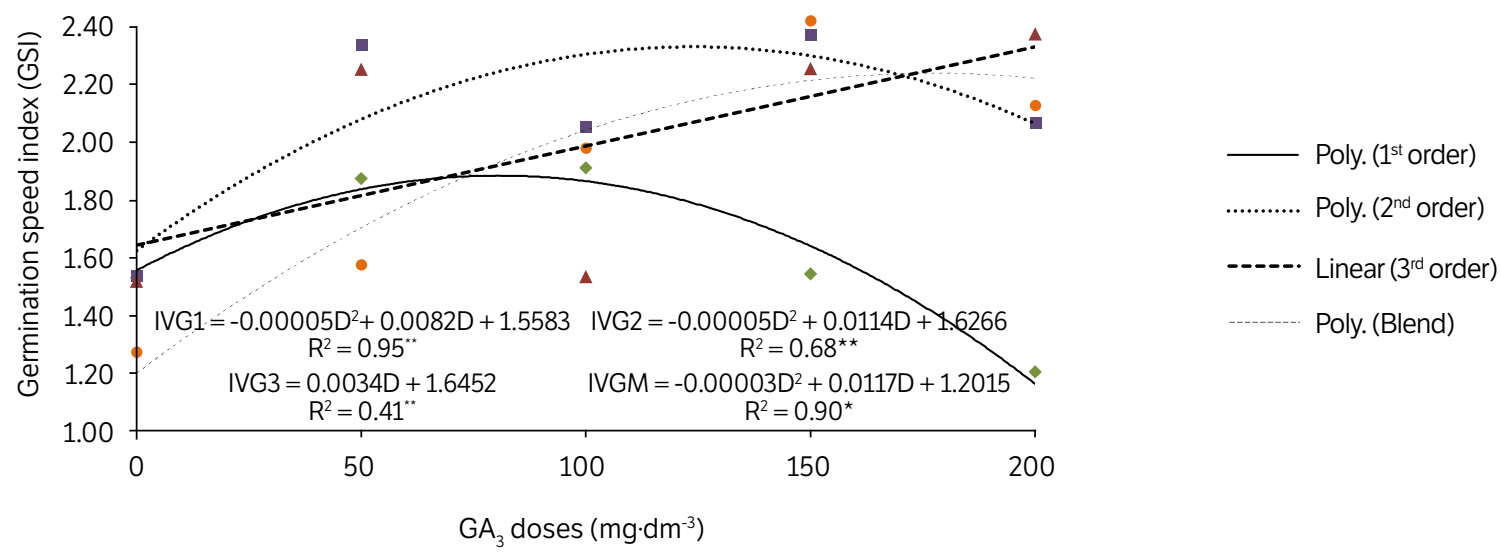

Figure 2. Effect of interaction between umbel orders and $\mathrm{GA}_{3}$ doses on germination speed index in Amazon chicory (Eryngium foetidum L.). 
The GSI is an essential parameter to determine seed vigor since it predicts the germination speed behavior. In this work, the use of $\mathrm{GA}_{3}$ at the maximum dose $\left(200 \mathrm{mg} \cdot \mathrm{dm}^{-3}\right)$ increased GSI by $83 \%$ as compared to the control treatment within the same umbel order. However, this germination rate is still considered low when GSI is compared to other Apiaceae species, such as carrots, which presents GSI above 9 (Santos et al. 2010).

For AGT, there was no significant interaction between order factors and doses of $\mathrm{GA}_{3}$, but significant differences for inflorescence order were observed, as an isolated factor (Table 3). The blend of seeds from different orders led to the longest AGT (11 days), in counterpart to the shortest AGT observed in seeds from the second order of inflorescence (nine days). These results indicate the relationship of umbel order with seed maturity degrees and reinforce the hypothesis that the mix of seeds compromises the overall quality demanded by the germination and seedling establishment (Ekpong and Sukprakarn 2006).

Regarding the $\% \mathrm{G}$, the best treatment combination was obtained by the interaction between secondary umbels and the GA3 $200 \mathrm{mg} \cdot \mathrm{dm}^{-3}$ dose (Fig. 3). Thus, by estimating the highest $\% \mathrm{G}$ of chicory seeds through equation adjustment $\left(\mathrm{R}^{2}=0.75\right)$, a germination percentage of $3.35 \%$ was reached.

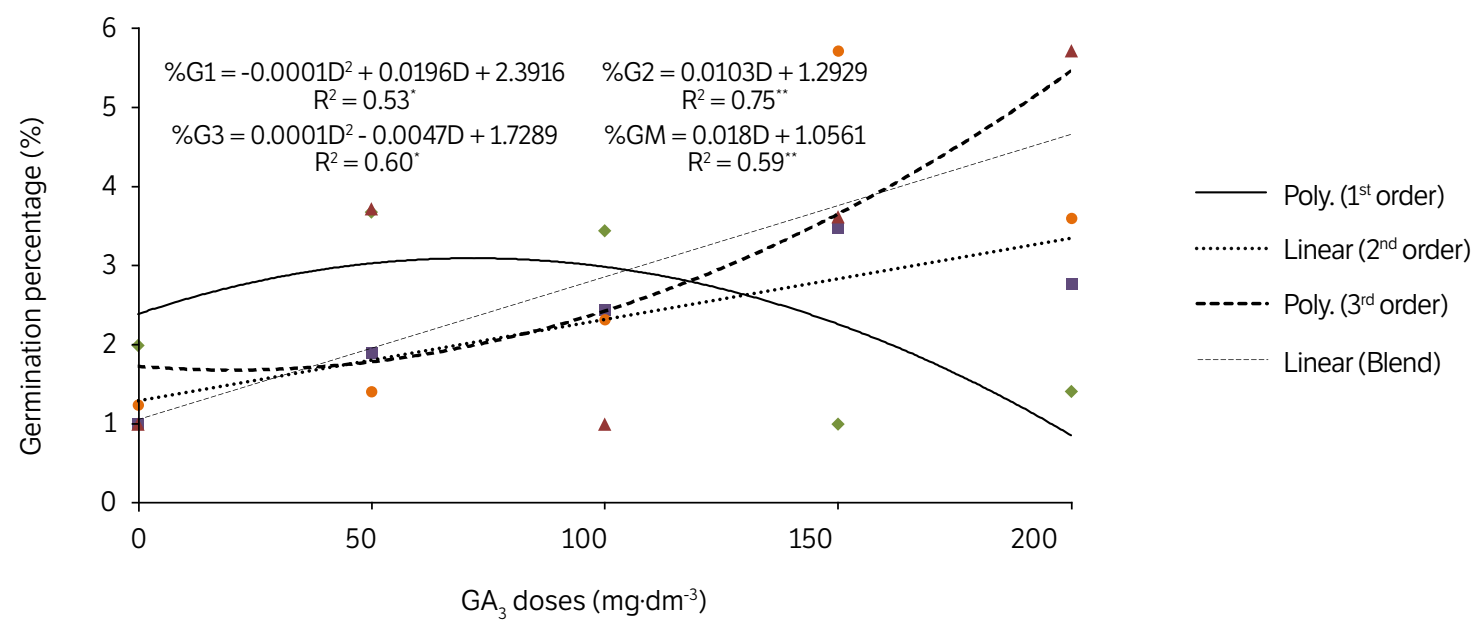

Figure 3. Effect of interaction between umbel orders and GA3 doses on germination percentage in Amazon chicory (Eryngium foetidum L.).

The low germination percentage observed in the present study-even in GA3-treated seeds-may still be linked to the presence of germination inhibitory substances in the seed coat, such as coumarin (Mozumder et al. 2017), widely distributed in Apiaceae species (Ribeiro and Kaplan 2002). In this study, the presence of coumarin was not determined. Finally, it is worth mentioning that only the ability to produce normal seedlings was considered for seed germination estimation, which may have contributed to the low observed germination rates.

The \%AS displayed a linear model $\left(\mathrm{R}^{2}=0.93\right)$, with an increase in \%AS in response to GA3 dose increases (up to $200 \mathrm{mg} \cdot \mathrm{dm}^{-3}$ ), observed only for the blend of seeds from different umbels, reaching the maximum of $8.87 \%$ (Fig. 4). This result may be related to the wide range of seed maturation degrees obtained in seeds from different umbels, which is a consequence of the indeterminate growth pattern demonstrated by this species (Silva et al. 2016).

For the \%NGS, there was a better fitting adjustment in a quadratic model for secondary umbel seeds and the $150 \mathrm{mg} \cdot \mathrm{dm}^{-3}$ $\mathrm{GA}_{3}$ dose in combination (Fig. 5). When the minimum dose of $\mathrm{GA}_{3}\left(149.25 \mathrm{mg} \cdot \mathrm{dm}^{-3}\right)$ is estimated, observed values of $4.24 \%$ NGS are obtained.

Therefore, seeds of Amazon chicory from secondary umbels combined with GA3 showed an increased \%G by probably reversing their natural dormancy imposed by inhibitory substances such as coumarin, a compound usually found in Amazon chicory.

This behavior was also evidenced in Solanum aethiopicum by Jorge et al. (2019), who observed that the application of $\mathrm{GA}_{3}$ increased seed germination on the $6^{\text {th }}(50 \%)$ and $14^{\text {th }}$ days $(77 \%)$, respectively at doses of 247 and $218 \mathrm{mg} \cdot \mathrm{L}^{-1}$. Kosera 
Neto et al. (2015), by evaluating different methods to improve seed germination rate in Solanum betaceum, demonstrated that $\mathrm{GA}_{2}$ application leads to increases of $90 \%$ in this variable.

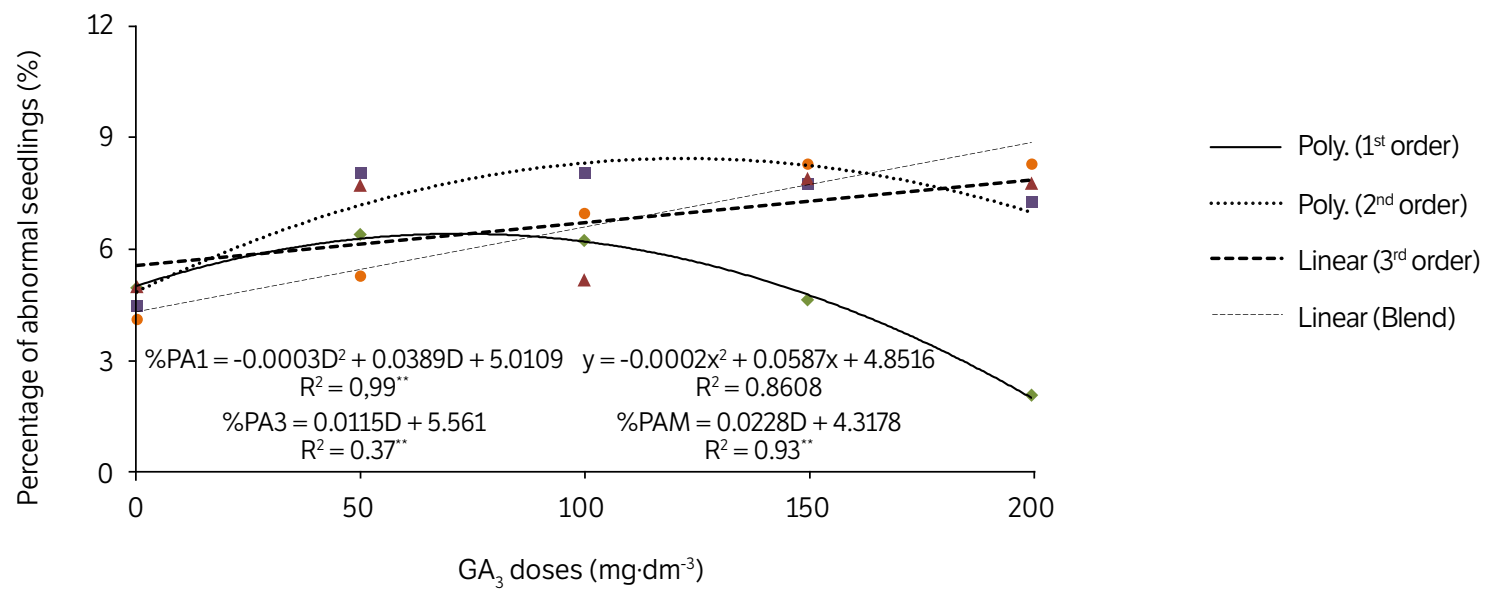

Figure 4. Effect of interaction between umbel orders and $\mathrm{GA}_{3}$ doses on percentage of abnormal seedlings in Amazon chicory (Eryngium foetidum $\mathrm{L}$.).

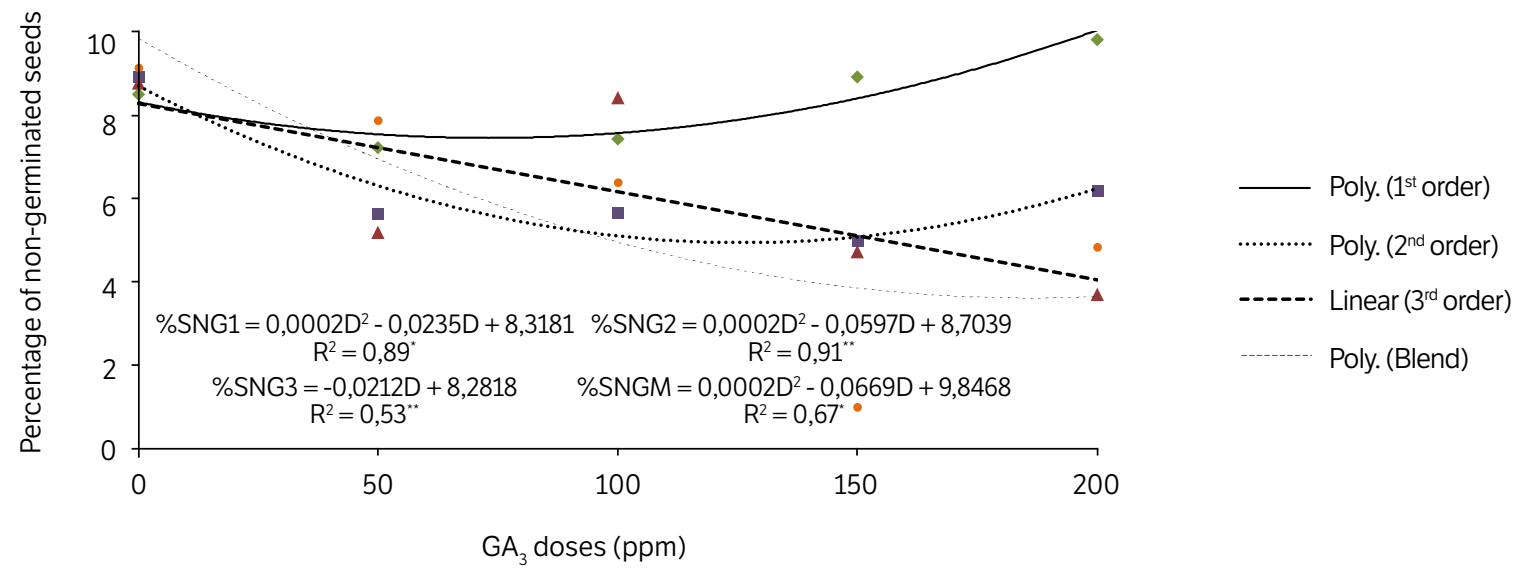

Figure 5. Effect of interaction between umbel orders and $\mathrm{GA}_{3}$ doses on percentage of non-germinated seeds (\%NGS) in Amazon chicory (Eryngium foetidum L.).

\section{CONCLUSION}

The highest production of seeds per plant was obtained by using the blend of seeds from different umbels $\left(1.41 \mathrm{~g} \cdot\right.$ plant $\left.^{-1}\right)$, with both number of umbels per order and seeds per plant being the major traits related to the enhanced yield.

The dose of $\mathrm{GA}_{3}$ at $200 \mathrm{mg} \cdot \mathrm{dm}^{-3}$ led to the best results in germination percentage in seeds from the secondary umbel. Regardless the $\mathrm{GA}_{3}$ application, seeds from secondary umbels showed the shortest AGT.

Studies concerning substances that may inhibit seed germination in E. foetidum are required to better understand the co-action of $\mathrm{GA}_{3}$ in improving fitness and seedling establishment in this species. Further studies are needed to reveal the biochemical and physiological aspects that underlie the overall quality of seeds from the second order of inflorescence. 


\section{AUTHORS' CONTRIBUTION}

Conceptualization: Moraes L. F., Gomes R. F. and Santos L. S.; Data Curation: Gomes R. F. and Santos L. S.; Formal Analysis: Gomes R. F. and Santos L. S.; Methodology: Moraes L. F., Gomes R. F. and Santos L. S.; Investigation: Moraes L. F. and Gomes R. F.; Writing - Original Draft: Andrade F. L. N., Gomes R. F. and Santos L. S.; Writing - Review and Editing: Andrade F. L. N., Gomes R. F. and Santos L. S.; Supervision: Gomes R. F.

\section{DATA AVAILABILITY STATEMENT}

Data will be available upon request.

\section{FUNDING}

Fundação Amazônia de Amparo a Estudos e Pesquisa

\section{ACKNOWLEDGMENTS}

The authors are thankful to the Programa de Iniciação Científica from Universidade Federal Rural da Amazônia and Fundação Amazônia de Amparo a Estudos e Pesquisa for the scholarship granted to the first author (LFM).

\section{REFERENCES}

Alvares, C. A., Stape, J. L., Sentelhas, P. C. Gonçalves, J. L. M. and Sparovek, G. (2013). Koppen's climate classification map for Brazil. Meteorologische Zeitschrift, 22(6), 711-728. https://doi.org/10.1127/0941-2948/2013/0507

Asif, M. (2015). Pharmacological activities and phytochemistry of various plant containing coumarin derivatives. Current Science Perspectives, 1(3), 77-90.

Barbosa, J. C. and Maldonado Júnior, W. (2015). Experimentação agronômica \& AgroEstat: Sistema para análises estatísticas de ensaios agronômicos. Jaboticabal: UNESP.

Baskin, J. M. and Baskin, C. C. (2004). A classification system for seed dormancy. Seed Science Research, 14(1), 1-16. https://doi. org/10.1079/SSR2003150

Brasil. Ministério da Agricultura, Pecuária e Abastecimento. (2009). Regras para análise de sementes. Brasília: SNDA/DNDV/CLAV.

Chen, B. X., Peng, Y. X., Gao, J. D., Zhang, Q., Liu, Q. J., Fu, H. and Liu, J. (2019). Coumarin-induced delay of rice seed germination is mediated by suppression of abscisic acid catabolism and reactive oxygen species production. Frontiers in Plant Science, $10,828$. https://doi.org/10.3389/fpls.2019.00828

Costa, C. J. (2012). Deterioração e armazenamento de sementes de hortaliças (Documentos 355). Embrapa: Clima Temperado.

Cravo, S. M., Viégas, I. J. M. and Brasil, E. C. (2007). Recomendações de adubação e calagem para o Estado do Pará. Belém: Embrapa Amazônia Oriental. 
Debeaujon, I. and Koornneef, M. (2000). Gibberellin requirement for Arabidopsis seed germination is determined both by testa characteristics and embryonic abscisic acid. Plant Physiology, 122(2), 415-424. https://doi.org/10.1104/pp.122.2.415

Ekpong, B. and Sukprakarn, S. (2006). Harvest stages and umbel order contribution on Eryngo (Eryngium foetidum L.) seed yield and quality. Kasetsart Journal Natural Science, 40, 273-279.

Gomes, R. F., Silva, J. P., Gusmão, S. A. L. and Souza, G. T. (2013). Produção de chicória da Amazônia cultivada sob densidades de cultivo e poda do pendão floral. Revista Caatinga, 26(3), 9-14.

Hussain, M. I., Abbas, S. Q. and Reigosa, M. J. (2018). Activities and novel applications of secondary metabolite coumarins. Planta Daninha, 36, 1-13. https://doi.org/10.1590/S0100-83582018360100016

Jorge, L. G., Torres, T. P., Martins, B. N. M., Ono, E. O. and Rodrigues, J. D. (2019). Concentrações de biorreguladores na germinação e emergência de jiló. Revista de Ciências Agrárias, 42(3), 704-711. https://doi.org/10.19084/rca.17478

Kosera Neto, C., Fabiane, K. C., Radaelli, J. C., Wagner Júnior, A. and Moura, G. C. (2015). Métodos para superação de dormência em sementes de tomateiro arbóreo (Solanum betaceum). Pesquisa Agropecuária Tropical, 45(4), 420-425. https://doi.org/10.1590/1983-40632015v4537332 Labouriau, L. G. (1983). A germinação das sementes. Washington, D.C.: Secretaria Geral da Organização dos Estados Americanos.

Lavagnini, C. G., Di Carne, C. A. V., Correa, F., Henrique, F., Tokumo, L. E., Silva, M. H. and Santos, P. C. S. (2014). Fisiologia vegetal: hormônio giberelina. Revista Científica Eletrônica de Agronomia, 25(1), 48-52.

Lopes, A. C. A. and Nascimento, W. M. (2012). Dormência em sementes de hortaliças (Documentos 136). Brasília: Embrapa Hortaliças. Maguire, J. D. (1962). Speed of germination aid in selection and evaluation for seedling emergence and vigor. Crop Science, 2(2), 176177. https://doi.org/10.2135/cropsci1962.0011183X000200020033x

Marcos Filho, J. (2015). Fisiologia de sementes de plantas cultivadas. 2. ed. Londrina: ABRATES, 660 p.

Mozumder, S. N. and Hossain, M. M. (2013). Effect of seed treatment and soaking duration on germination of Eryngium foetidum L. seeds. International Journal of Horticulture, 3, 46-51. https://doi.org/10.5376/ijh.2013.03.0010

Mozumder, S. N., Haque, M. I., Kamal, M. M., Akter, S. and Banik, B. R. (2017). Effect of storage, growth regulator treatment and seed priming on germination of Eryngium foetidum. International Journal of Advanced Multidisciplinary Research, 4(7), 16-21. https://doi. org/10.22192/ijamr.2017.04.07.004

Nakagawa, J. (2014). Os componentes da produtividade de sementes. Informativo Abrates, 24, 15-20.

Paul, J. H. A., Seaforth, C. E. and Tikasingh, T. (2011). Eryngium foetidum L. A review. Fitoterapia, 82(3), 302-308. https://doi.org/10.1016/j. fitote.2010.11.010

Prudente, D. O. and Paiva, R. (2018). Seed Dormancy and Germination: Physiological Considerations. Journal of Cell and Developmental Biology, 2(1), 2.

Quisen, R. C. and Angelo, P. C. S. (2008). Manual de procedimentos do laboratório de cultura de tecidos da Embrapa Amazônia Ocidental (Documentos 61). Manaus: Embrapa Amazônia Ocidental.

Razavi, S. M. (2011). Plant Coumarins as Allelopathic Agents. International Journal of Biological Chemistry, 5(1), 86-90. https://doi. org/10.3923/ijbc.2011.86.90

Ribeiro, C. V. C. and Kaplan, M. A. C. (2002). Tendências evolutivas de famílias produtoras de cumarinas em Angiospermae. Química Nova, 25(4), 533-538. https://doi.org/10.1590/S0100-40422002000400004

Santos, V. J., Garcia, D. C., Lopes, S. J. and Eichelberger, L. (2010). Qualidade fisiológica de sementes de cenoura classificadas por tamanho. Ciência Rural, 40(9), 1903-1908. https://doi.org/10.1590/S0103-84782010000900008 
Silva, P. P., Sekita, M. C., Dias, D. C. F. S. and Nascimento, W. M. (2016). Biochemical and physiological analysis in carrot seeds from different orders of umbels. Revista Ciência Agronômica, 47(2), 407-413. https://doi.org/10.5935/1806-6690.20160049

Singh, B. K., Ramakrishna, Y. and Ngachan, S. V. (2014). Spiny coriander (Eryngium foetidum L.): a commonly used, neglected spicingculinary herb of Mizoram, India. Genetic Resources and Crop Evolution, 61, 1085-1090. https://doi.org/10.1007/s10722-014-0130-5 